\title{
Model Regresi Data Panel Pada Kasus Infeksi Saluran Pernapasan Akut (ISPA) di Provinsi Nusa Tenggara Timur
}

\author{
Indah Magfirrah ${ }^{1}$, Astri Atti ${ }^{2}$, dan Maria A. Kleden ${ }^{3}$ \\ 1,2,3Program Studi Matematika, Fakultas Sains dan Teknik, \\ Universitas Nusa Cendana, Kupang, 85228, Indonesia \\ * Corresponding author, email: magfirrahindah@gmail.com
}

\begin{abstract}
Acute respiratory infection (ARI) is an infectious desease cause by bacteria or viruses that attack the respiratory organs. This research aims to determine the best panel data regression model in the case of the factors that influence the number of patients with ARI in East Nusa Tenggara Province from 2014 to 2018. Response variable used is the number of ARI patients. Independent variables were observed among others, low birth weight, malnutrition, immunization, exclusive breastfeeding, and vitamin A in 22 districts or city in East Nusa Tenggara. The results showed that the Random Effect Models eliminate outlier data on response variable is a model that can describe the influence of independent variables on the number of patients with ARI in East Nusa Tenggara Province from 2014 to 2018. Variables that influence of ARI are malnutrition and exclusive breastfeeding with a coefficient of determination $(R)$ of 9,2\%.
\end{abstract}

Keywords: ARI, Outlier, Random Effects Model.

\begin{abstract}
Abstrak
Infeksi saluran pernapasan akut (ISPA) merupakan penyakit menular yang disebabkan oleh bakteri atau virus yang menyerang organ pernapasan. Kasus ISPA pada balita disebut pneumonia. Penelitian ini bertujuan untuk menentukan model regresi data panel terbaik pada kasus faktor-faktor yang mempengaruhi jumlah penderita ISPA di Provinsi Nusa Tenggara Timur dari tahun 2014 sampai 2018. Peubah respon yang digunakan adalah jumlah penderita ISPA. Peubah bebas yang diamati antara lain berat badan lahir rendah(BBLR), gizi buruk, imunisasi, ASI eksklusif, dan vitamin a pada 22 kabupaten/kota di Provinsi Nusa Tenggara Timur. Hasil penelitian menunjukkan bahwa random effect model dengan mengeliminasi data outlier pada variabel respon merupakan model yang dapat menggambarkan pengaruh peubah bebas terhadap jumah penderita ISPA di Provinsi Nusa Tenggara Timur dari tahun 2014 sampai 2018. Peubahpeubah yang berpengaruh terhadap jumlah penderita ISPA adalah gizi buruk dan ASI eksklusif dengan koefisien determinasi $\left(\mathrm{R}^{2}\right)$ sebesar $9,2 \%$.
\end{abstract}

Kata Kunci: ISPA, Outlier, Random Effect Model.

\section{Pendahuluan}

Pneumonia adalah pembunuh utama balita di dunia, lebih banyak dibanding dengan gabungan penyakit AIDS, malaria dan campak. Di dunia setiap tahunnya diperkirakan lebih dari 2 juta balita meninggal karena pneumonia. Besarnya kematian ini menyebabkan pneumonia disebut sebagai "pandemi yang terlupakan" atau "the forgotten pandemic", akan tetapi tidak banyak perhatian yang diberikan sehingga pneumonia disebut juga pembunuh balita yang terlupakan atau "the forgotten killer of children" [1]. 
Di Indonesia, menurut data Riset Kesehatan Dasar Riskesdas (2007) Pneumonia menduduki peringkat kedua sebagai penyebab kematian bayi $(23,8 \%)$ dan balita $(15,5 \%)$. Data Riskesdas(2013) digambarkan bahwa period prevalens dari pneumonia tahun 2013 adalah 1,8\% dan 4,5\%. Berdasarkan data Laporan Rutin Subdit ISPA Tahun 2017, didapatkan insiden (per 1000 balita) di Indonesia sebesar 20,54\%. Pada tahun 2017, Angka kematian akibat Pneumonia pada kelompok bayi lebih tinggi yaitu sebesar 0,56\% dibandingkan pada kelompok anak umur $1-4$ tahun sebesar 0,23\% [2].

Dalam Riskesdas (2007), Nusa Tenggara Timur juga merupakan provinsi tertinggi period prevalence ISPA. Period prevalence ISPA di Provinsi Nusa Tenggara Timur menurut Riskesdas 2013 (41,7\%) tidak jauh berbeda dengan 2007, dimana Kabupaten/kota yang tertinggi prevalensi ISPA-nya adalah Sumba Tengah (69\%) dan terendah Manggarai (22\%). Profil Kesehatan Kabupaten/Kota se-Provinsi NTT menunjukkan Cakupan penemuan dan penanganan Pneumonia pada balita mengalamai fluktuasi dari tahun 2014 - 2017. Pada tahun 2014 sebesar 3.714 kasus (13\%), tahun 2015 sebanyak 3.079 kasus (4,94\%), tahun 2016 sebanyak 3.683 kasus (5,87\%) dan tahun 2017 sebesar 6.049 kasus $(9,99 \%)$ [3]. Berdasarkan cakupan penemuan dan penanganan pneumonia yang mengalami fluktuasi, maka diperlukan analisis yang mengamati data gabungan antara data lintas lokasi (cross section) dan data deret waktu (time series).

Data panel adalah gabungan dari data lintas lokasi dan data deret waktu. Data lintas lokasi merupakan data beberapa lokasi yang diamati dalam satu waktu tertentu, sedangkan data deret waktu merupakan data satu lokasi yang diamati dari beberapa periode waktu [4]. Dengan demikian data panel merupakan data beberapa lokasi yang diamati secara berulang-ulang di beberapa periode waktu tertentu. Terdapat beberapa keunggulan dalam menggunakan data panel dibandingkan dengan data lintas lokasi atau deret waktu saja. Keunggulan itu antara lain, memberikan informasi yang lebih banyak, data memiliki variabilitas yang besar dan mengurangi kolinieritas antar peubah bebas sehingga menghasilkan pendugaan yang lebih efisien, serta mengontrol keheterogenan lokasi yang tidak teramati.

Apabila analisis terhadap Kasus Infeksi Saluran Pernapasan Akut hanya menggunakan data lintas lokasi yang mengamati hanya pada satu titik waktu, sehingga perkembangan Kasus Infeksi Saluran Pernapasan Akut dari waktu ke waktu tidak dapat terlihat. Begitupun jika hanya menggunakan data deret waktu yang hanya mengamati satu lokasi, sehingga perkembangan Kasus Infeksi Saluran Pernapasan Akut tidak dapat terlihat untuk beberapa lokasi. Berdasarkan hal tersebut maka penelitian ini menerapkan analisis regresi data panel dengan lokasi berupa kabupaten dan kota untuk melakukan pemodelan jumlah Kasus Infeksi Saluran Pernapasan Akut di Prov. Nusa Tenggara Timur. 


\section{Material dan Metode}

Data yang digunakan dalam penelitian ini adalah data sekunder yang diperoleh dari Dinas Kesehatan (DINKES) Provinsi Nusa Tenggara Timur. Data yang diambil adalah 22 kabupaten/kota di Provinsi Nusa Tenggara Timur pada tahun 2014 sampai dengan 2018. Variabel dalam penelitian ini terdiri dari dua macam, yaitu variabel bebas (independent variables) dan variabel terikat (dependent variables). Adapun yang menjadi variabel bebas dalam penelitian ini adalah BBLR $\left(\mathrm{X}_{1}\right)$, Gizi Buruk $\left(\mathrm{X}_{2}\right)$, Imunisasi $\left(\mathrm{X}_{3}\right)$, ASI Eksklusif $\left(\mathrm{X}_{4}\right)$ dan Vitamin A $\left(\mathrm{X}_{5}\right)$ Sedangkan ISPA (Y) merupakan variabel terikatnya. Penelitian ini dibantu menggunakan paket software Eviews $11 \mathrm{SV}$.

\subsection{Model Regresi Data Panel}

Analisis regresi data panel adalah analisis regresi yang didasarkan pada data panel untuk mengamati hubungan antara satu variabel terikat (dependent variable) dengan satu atau lebih variabel bebas(independent variable). Dalam mengestimasi model regresi data panel, terdapat tiga pendekatan yang biasa digunakan, yaitu Common Effect Model (CEM), Fixed Effect Model (FEM), dan Random Effect Model (REM). Pendekatan Common Effect Model secara sederhana meggabungkan seluruh data time series dan cross section, oleh karena itu Common Effect Model diestimasi dengan cara OLS (Ordinary Least Square). Pendekatan Fixed Effect Model mencerminkan perbedaan pada konstanta untuk cross section atau time series. Estimasi Fixed Effect Model dilakukan dengan cara menambahkan variabel dummy (Least Square Dummy Variable atau LSDV). Pendekatan Random Effect Model memperhatikan efek istilah error di dalam model, yaitu komponen error dalam cross section, maupun komponen error dalam time series. Estimasi Random Effect Model dilakukan dengan cara Generalized Least Square (GLS) [5].

\subsection{Penentuan Model Regresi Data Panel}

\section{Uji Chow}

Uji ini digunakan untuk memilih salah satu model pada regresi data panel, yaitu antara Fixed Effect Model dengan Common Effect Model. Asumsi bahwa setiap unit cross section memiliki perilaku yang sama cenderung tidak realistis mengingat dimungkinkannya setiap unit cross section memiliki perilaku yang berbeda. Prosedur pengujiaannya sebagai berikut :

Hipotesis :

$H_{0}: \alpha_{1}=\alpha_{2}=\ldots=\alpha_{n}=0$ (Common Effect Model $)$

$H_{1}$ : Minimal ada satu $\alpha_{i} \neq 0$ (Fixed Effect Model)

Statistik uji yang digunakan merupakan uji $\mathrm{F}$, yaitu:

Keterangan:

$$
F_{\text {hit }}=\frac{[R R S S-U R S S] /(N-1)}{U R S S /(N T-N-K)}
$$

$N=$ Jumlah individu (cross section)

$T=$ Jumlah periode waktu (time series) 
$K=$ Jumlah variabel penjelas

$$
\begin{gathered}
R R S S=\text { Restricted residual sums of squares } \\
U R S S=\text { Unrestricted residual sums of squares }
\end{gathered}
$$

Jika nilai $F_{\text {hitung }}>F_{(N-1, N T-N-K)}$ atau $p$-value $<\alpha$ (taraf signifikansi/alpha), maka tolak hipotesis awal $\left(H_{0}\right)$ sehingga model yang terpilih adalah Fixed Effect Model [6].

2. Uji Hausman

Uji ini digunakan untuk memilih Random Effect Model atau Fixed Effect Model. Untuk mengetahui Random Effect dapat dibuat asumsi mengenai korelasi antara komponen sisaan dan peubah bebasnya. Jika diasumsikan tidak terdapat korelasi antara sisaan dengan peubah bebas maka model yang sesuai adalah Random Effect Model dan sebaliknya adalah Fixed Effect Model.

Hipotesis:

$H_{0}: \operatorname{corr}\left(X_{i t} \varepsilon_{i t}\right)=0$ (REM atau tidak ada hubungan)

$H_{1}: \operatorname{corr}\left(X_{i t} \varepsilon_{i t}\right) \neq 0$ (FEM atau ada hubungan)

Statistik uji yang digunakan adalah uji chi-square berdasarkan kriteria Wald, yaitu :

$$
\begin{gathered}
W=\hat{q}^{\prime}\left[\operatorname{var}\left(\hat{q}^{\prime}\right)\right]^{-1} \hat{q} \\
\Leftrightarrow W=\left(\hat{\beta}_{F E M}-\hat{\beta}_{R E M}\right)^{\prime}\left[\operatorname{var}\left(\hat{\beta}_{F E M}-\hat{\beta}_{R E M}\right)\right]^{-1}\left(\hat{\beta}_{F E M}-\hat{\beta}_{R E M}\right)
\end{gathered}
$$

Keterangan:

$\hat{\beta}_{F E M}$ : vektor koefisien peubah bebas dari Fixed Effect Model

$\hat{\beta}_{R E M}$ : vektor koefisien peubah bebas dari Random Effect Model

Jika nilai $W>\chi_{(k, \alpha)}^{2}$ dengan $k$ banyaknya peubah bebas atau nilai $p$-value $<\alpha$, maka tolak hipotesis awal $\left(H_{0}\right)$ sehingga model yang terpilih adalah Fixed Effect Model [5].

\section{Hasil dan Diskusi}

\subsection{Analisis Statistik Deskriptif}

Deskriptif jumlah penderita ISPA pertahun di Prov. NTT yang memuat rataan, simpanan baku, nilai minimum, nilai maksimum dan total jumlah penderita ISPA disajikan pada Tabel 1 berikut.

Tabel 1 Deskriptif jumlah penderita ISPA pertahun di Prov. NTT

\begin{tabular}{cccccc}
\hline Tahun & Rataan & $\begin{array}{c}\text { Simp. } \\
\text { Baku }\end{array}$ & Min & Maks & Total \\
\hline 2014 & 168,82 & 188,917 & 0 & 632 & 3714 \\
2015 & 139,95 & 131,328 & 0 & 404 & 3079 \\
2016 & 167,41 & 166,918 & 0 & 528 & 3683 \\
2017 & 274,95 & 556,571 & 0 & 2700 & 6049 \\
2018 & 160,41 & 170,786 & 0 & 756 & 3529 \\
\hline
\end{tabular}


Berdasarkan Tabel 1 menunjukkan bahwa dari tahun 2014 sampai 2018 nilai rataan jumlah penderita ISPA cenderung tidak stabil. Pada tahun 2014 nilai rataan jumlah penderita ISPA sebesar 168,82 jiwa perkabupaten dan kota dan tahun berikutnya tahun 2015 mengalami penurunan namun kemudian mengalami peningkatan maupun penurunan hingga tahun 2018. Adapun nilai keragaman jumlah penderita ISPA yang terkecil dari keseluruhan pada tahun 2015. Secara keseluruhan total jumlah penderita ISPA di Prov. NTT terbesar adalah pada tahun 2017, yaitu sebanyak 6049 jiwa.

\subsection{Penentuan Model Estimasi Regresi Data Panel}

1. Uji Chow

Uji Chow digunakan untuk memilih salah satu model pada regresi data panel, yaitu antara Common Effect Model atau Fixed Effect Model. Berdasarkan hasil pengujian didapatkan nilai $p$-value adalah 0,0040 dan nilai $F_{\text {hitung }}$ adalah 2,3028. Diketahui $F_{\text {tabel }}$ adalah 1,70 dengan taraf signifkan $\alpha=5 \%$. Nilai $F_{\text {hitung }}>F_{\text {tabel }}$ atau $p$-value $<\alpha$ maka $H_{0}$ ditolak yang berarti model regresi yang digunakan adalah Fixed Effect Model.

2. Uji Hausman

Uji Hausman digunakan untuk memilih Random Effect Model atau Fixed Effect Model. Berdasarkan hasil pengujian didapatkan nilai $P$-value adalah 0,8552 dan nilai $\chi_{\text {hitung }}^{2}$ adalah 1,9561. Diketahui $\chi_{\text {tabel }}^{2}$ adalah 11,070 dengan taraf signifkan $\alpha=5 \%$. Nilai $\chi_{\text {hitung }}^{2}<\chi_{\text {tabel }}^{2}$ atau $p$-value lebih besar $\alpha$ maka $H_{0}$ diterima yang berarti model regresi yang digunakan adalah Random Effect Model.

\subsection{Deteksi Penyimpangan Asumsi Klasik}

1. Uji Multikolinieritas

Uji multikolinieritas dapat dilakukan dengan menggunakan matriks korelasi. Berdasarkan hasil pengujian dapat diketahui hubungan antar variabel independent tidak menunjukkan korelasi > 0,9. Sehingga dapat disimpulkan bahwa semua variabel independen dalam model terbebas multikoliniaritas.

2. Uji Kenormalan sisaan

Uji kenormalan sisaan dapat dilakukan dengan menggunakan uji Jarque-Bera (JB). Berdasarkan hasil pengujian, nilai statistik uji Jarque-Bera sebesar 12780,30 dengan pvalue adalah 0,0000 sementara nilai $x_{(5 ; 0,05)}^{2}$ adalah 11,070 . karena nilai statistik uji Jarque-Bera lebih besar dari $x_{\text {tabel }}^{2}$ dan nilai $p$-value $<\alpha$, sehingga dapat disimpulkan tolak $\mathrm{H}_{0}$ artinya bahwa sisaan tidak menyebar normal.

3. Uji kebebasan Autokorelasi

Pengujian autokorelasi dapat menggunakan nilai uji Durbin-Watson (d) Berdasarkan hasil pengujian nilai Durbin-Watson stat (d) adalah 2,1456 dan 4-dU adalah 2,2149 dengan $n=110$. Karena nilai $\mathrm{dU} \leq \mathrm{d} \leq 4-\mathrm{dU}$ sehingga dapat disimpulkan menerima hipotesis nol yang berarti tidak ada autokorelasi. 


\section{Uji Kehomogenan Ragam Sisaan}

Uji Kehomogenan Ragam Sisaan dapat dilakukan dengan menggunakan uji glejser. Berdasarkan hasil pengujian nilai p-value variabel BBLR, Gizi Buruk, Imunisasi, ASI Eksklusif dan Vitamin A lebih besar dari $\alpha$. Maka dapat disimpulkan bahwa terima $\mathrm{H}_{0}$ artinya tidak terjadi heteroskedastisitas pada model persamaan regresi data panel.

5. Mengatasi sisaan tidak menyebar normal

Berdasarkan hasil pengujian, nilai statistik uji Jarque-Bera sebesar 12780,30 lebih besar dari $x_{\text {tabel }}^{2}$ artinya sisaan tidak menyebar normal. Sehingga untuk mengatasinya dengan mengeliminasi data outlier pada variabel dependennya. Kemudian berdasarkan hasil pengujian asumsi kembali didapatkan nilai statistik uji Jarque-Bera sebesar 7,5035 dengan $p$-value $=0,0235$ sementara nilai $x_{(5 ; 0,01)}^{2}=15,086$. karena nilai statistik uji Jarque-Bera $<x_{\text {tabel }}^{2}$ dan nilai $p$-value $>\alpha$, sehingga dapat disimpulkan terima $\mathrm{H}_{0}$ artinya bahwa sisaan menyebar normal.

\subsection{Pengujian Signifikansi Parameter}

1) Uji Simultan

Berdasarkan hasil pengujian didapatkan $p$-value $=0,023$ dan nilai $\mathrm{F}_{\text {hitung }}$ adalah 2,75. Diketahui nilai $\mathrm{F}_{\text {tabel }}$ adalah 1,70 dengan taraf signifikan 5\%. Nilai $\mathrm{F}_{\text {hitung }}>\mathrm{F}_{\text {tabel }}$ atau $p$ value $<\alpha$. maka tolak $\mathrm{H}_{0}$ sehingga dapat disimpulkan bahwa ada pengaruh variabel independen terhadap variabel dependen atau ISPA pada balita.

2) Uji Parsial

Pengujian parameter secara parsial dapat disajikan pada Tabel 2 berikut:

Tabel 2 Uji Parsial

\begin{tabular}{llcc}
\hline \multicolumn{1}{c}{ Variabel } & Estimate & $p$-value & Kesimpulan \\
\hline $\operatorname{BBLR}\left(\mathrm{X}_{1}\right)$ & 0,055471 & 0,1117 & Tidak Berpengaruh \\
Gizi Buruk $\left(\mathrm{X}_{2}\right)$ & 0,321723 & 0,0330 & Berpengaruh \\
Imunisasi $\left(\mathrm{X}_{3}\right)$ & $-0,005283$ & 0,3474 & Tidak Berpengaruh \\
ASI Eksklusif $\left(\mathrm{X}_{4}\right)$ & 0,006861 & 0,0236 & Berpengaruh \\
Vitamin $\mathrm{A}\left(\mathrm{X}_{5}\right)$ & 0,000312 & 0,8127 & Tidak Berpengaruh \\
\hline
\end{tabular}

Berdasarkan Tabel 2 dapat dilihat bahwa dari lima variabel bebas yang digunakan, terdapat dua variabel yang signifikan terhadap variabel respon yaitu gizi buruk dan ASI Eksklusif. Maka diambil keputusan tolak $\mathrm{H}_{0}$ atau dapat dikatakan variabel gizi buruk $\left(\mathrm{X}_{2}\right)$ dan ASI $\left(\mathrm{X}_{4}\right)$ berpengaruh secara signifikan terhadap penyebaran penyakit ISPA di Provinsi Nusa Tenggara Timur.

3) Koefisien Determinasi

Berdasarkan hasil pengujian nilai koefisien determinasi $\left(\mathrm{R}^{2}\right)$ model adalah 0,092007. Hal ini berarti bahwa sebesar 9,2\% keragaman dalam kasus ISPA mampu dijelaskan oleh model regresi, sedangkan sisanya yaitu 90,8\% dijelaskan oleh faktor lain diluar model. 
Meskipun nilai $\mathrm{R}^{2}$ kecil tetapi dari uji $\mathrm{F}$ sudah menunjukkan bahwa model dapat digunakan.

\subsection{Model Akhir Regresi Data Panel}

Berdasarkan pengujian yang telah dilakukan diperoleh model akhir regresi data panel untuk kasus ISPA di Prov. NTT yaitu Random Effect Model sebagai berikut:

$$
I S P A_{\mathrm{it}}=\widehat{\alpha}_{\mathrm{i}}+0,304047 \text { Gizi Buruk }_{\mathrm{it}}+0,007176 \mathrm{ASI}_{\mathrm{it}}
$$

Dimana besaran nilai intersep $\hat{\alpha}_{i}$ berbeda-beda untuk setiap kabupaten/kota yang tersaji dalam Tabel 3 berikut:

Tabel 3 Nilai intersep setiap Kabupaten/Kota

\begin{tabular}{cllcll}
\hline $\begin{array}{c}\text { Indeks } \\
(\mathrm{i})\end{array}$ & Kab/kota & \multicolumn{2}{c}{$\widehat{\boldsymbol{\alpha}}_{\mathbf{i}}$} & $\begin{array}{c}\text { Indeks } \\
\text { (i) }\end{array}$ & \multicolumn{2}{c}{ Kab/kota } & $\widehat{\boldsymbol{\alpha}}_{\mathbf{i}}$ \\
\hline 1 & Kota Kupang & 61,2125 & 12 & Ngada & 123,7492 \\
2 & Kupang & 174,8310 & 13 & Manggarai Timur & 93,3655 \\
3 & TTS & 146,9003 & 14 & Manggarai & 100,0641 \\
4 & TTU & 93,4598 & 15 & Manggarai Barat & 179,3135 \\
5 & Belu & 106,6719 & 16 & Sumba Barat Daya & 30,0809 \\
6 & Alor & $-25,8231$ & 17 & Sumba Barat & 99,0308 \\
7 & Lembata & 85,9908 & 18 & Sumba Tengah & 142,1991 \\
8 & Flotim & 211,9294 & 19 & Sumba Timur & 105,8139 \\
9 & Sikka & 51,3365 & 20 & Rote Ndao & 28,3475 \\
10 & Ende & 103,1246 & 21 & Sabu Raijua & $-6,7166$ \\
11 & Nagekeo & 73,6301 & 22 & Malaka & 18,3910 \\
\hline
\end{tabular}

Berdasarkan model pada persamaan (1), maka kesimpulan yang dapat diambil adalah:

1) Dengan menganggap variabel ASI Eksklusif konstan, setiap penambahan satu balita yang gizi buruk maka akan meningkatkan ISPA sebesar 0,304 kasus

2) Dengan menganggap variabel gizi buruk konstan, setiap penambahan satu balita yang diberikan ASI Eksklusif maka akan meningkatkan ISPA sebesar 0,007 kasus

Nilai intercept masing-masing kabupaten/kota berbeda, ada yang bertanda positive dan negative. Kabupaten/kota yang bertanda negative yaitu Kabupaten Alor sebesar 25,8231 dan Kabupaten Sabu Raijua sebesar -6,7166. Sehingga besaran intercept/konstanta menunjukkan bahwa jika variabel dependennya diasumsikan konstan, maka variabel dependen yaitu ISPA akan menurun sebesar 25,823\% untuk Kabupaten Alor dan 6,7166\% untuk Kabupaten Sabu Raijua. Begitupun sebaliknya, jika intercept bertanda positive maka akan meningkatkan ISPA sebesar intercept tiap kabupaten/kota tersebut. 


\section{Kesimpulan}

Berdasarkan analisis dan pembahasan yang telah dipaparkan mengenai pemodelan ISPA pada balita di Prov. NTT menggunakan metode Regresi Data Panel diperoleh kesimpulan sebagai berikut :

1. Berdasarkan hasil analisis penentuan model regresi data panel dengan pendekatan common effect model, fixed effect model, dan random effect model, maka didapatkan model regresi data panel yang lebih sesuai untuk pemodelan kasus ISPA di Provinsi Nusa Tenggara Timur adalah random effect model, dengan model persamaan hasil estimasi sebagai berikut:

$I S P A_{\text {it }}=\widehat{\alpha}_{\mathrm{i}}+0,304047$ Gizi Buruk $_{\text {it }}+0,007176$ ASI $_{\text {it }}$

2. Pada pendekatan Random effect model didapatkan $\mathrm{R}^{2}$ sebesar 0,092007 , artinya kemampuan variabel gizi buruk dan ASI Eksklusif secara bersama-sama mempengaruhi variabel ISPA sebesar 9,2\% sedangkan sisanya sebesar 90,8\% dijelaskan oleh variabel lain yang pengaruhnya lebih besar dari variabel yang ada dan seluruh variabel bebas signifikan secara statistik pada $\alpha=5 \%$ yang berarti mempunyai pengaruh yang signifikan terhadap variabel ISPA.

\section{Daftar Pustaka}

[1] World Health Organization (WHO). Pneumonia: The Forgotten Killer of Children, 2006.

[2] Kemenkes RI. Profil Kesehatan Indonesia tahun 2017, 2018.

[3] Dinas Kesehatan Provinsi NTT. Profil Kesehatan NTT Tahun 2016. Kupang: DinKes NTT, 2017.

[4] Baltagi, B. H. Econometric Analysis of Panel Data. Ed ke-3, Chichester : John Wiley and Sons Ltd, 2005.

[5] Jaya, I. G. N. M., \& N. Sunengsih. Kajian Analisis Regresi dengan Data Panel. Prosiding Seminar Nasional Penelitian. Yogyakarta: Universitas Negeri Yogyakarta, 2009.

[6] Greene, Wiliam H. Econometric Analysis Ed ke-7. London : Pearson Education, 2012. 